\title{
Characterisation of liver membrane autoantibodies determined by indirect immunofluorescence
}

\author{
U TAGE-JENSEN, H PERMIN, K KROGSGAARD
}

From the Laboratory of Immunology, Department M, Rigshospitalet and the Division of Hepatology, Hvidovre Hospital, Copenhagen

SUMMARY Indirect immunofluorescence studies were performed using sera and IgG-Fab $\mathrm{b}_{2}$ fragments from patients with chronic active hepatitis (CAH) who were positive for a liver membrane antibody (LMA). The specificity was investigated using hepatocytes from humans as well as rabbit, rat, guinea pig and monkey. Only sera also positive for smooth muscle antibody gave staining of lymphocytes and absorption with F-actin from rabbit muscle abolished this as well as all other smooth muscle staining without influencing LMA.

It was concluded that LMA, routinely detected by indirect immunofluorescence using rabbit hepatocytes, represents specific binding to non-species-specific membrane antigens which are normal constituents of human hepatocytes. The antigen is separately located, and not cross-reactive with F-actin.

Liver membrane autoantibody (LMA) was first detected by Hopf $e t$ al ${ }^{1}$ in patients with HBsAgnegative chronic active hepatitis (CAH) using an indirect immunofluorescence (IF) test. Later studies confirmed that LMA is primarily found within this disease group, but it was also sporadically demonstrated in acute hepatitis, alcoholic cirrhosis and Sjögren's syndrome. ${ }^{2-5}$

Absorption studies using a liver-specific membrane lipoprotein (LSP) ${ }^{6}$ first indicated that this was the target antigen for LMA, ${ }^{1}$ but further studies using affinity chromatography and crossed immunoelectrophoresis disclosed that LMA was directed against a soluble liver membrane antigen (LMAg) which is also non-species specific, but not a constituent of LSP. ${ }^{7}$ That study also concluded, from indirect evidence, that LMAg was unlikely to crossreact with F-actin, which was shown to be a constituent of hepatocyte membranes. ${ }^{8}$

The present study is concerned with a further characterisation of LMA detected by indirect IF, especially concerning its organ- and species-specificity and the possible influence of binding to Fc receptors and actin of hepatocyte membranes.

\section{Material and methods}

PATIENTS

Sera from eight female patients with HBsAg-

Accepted for publication 7 July 1981 negative biopsy-verified CAH were included in this study. Age, sex and serological status are listed in the Table. All sera were drawn at the time of liver biopsy and without prior heat inactivation they were stored at $-20^{\circ} \mathrm{C}$ until use. Sera from eight control persons, matched for sex and age were included. None of these controls demonstrated autoantibodies in serum.

SEROLOGICAL TESTS

Sera were tested for LMA, antinuclear antibodies (ANA), smooth muscle antibodies (SMA) and antimitochondrial antibodies (AMA) of IgG class by the indirect IF test as previously described by Tage-Jensen et al.4 Sera were tested blindfold in appropriate dilutions: LMA 1/4; ANA, SMA, AMA 1/16. HBsAg was tested using radioimmunoassay (Ausria-II, Abbott Laboratories, Ill.).

\section{CELL SUSPENSIONS}

Suspensions of hepatocytes were made from livers of rabbit, rat, guinea pig, and monkey using perfusion with enzyme-free solutions and mechanical disruption. ${ }^{1}$ Further, hepatocyte suspensions were prepared from human liver tissue obtained by percutaneous biopsy as described in detail elsewhere. ${ }^{19}$ Liver tissue for these experiments was obtained from three different patients. Indication for biopsy was suspicion of alcoholic liver disease, but only minor histological changes such as steatosis or non-specific reactive changes were found. 
Serological data from eight female patients with HBsAg-negative chronic active hepatitis and eight age-matched female controls

\begin{tabular}{|c|c|c|c|c|c|c|c|}
\hline \multirow[t]{4}{*}{ Patient No } & \multirow[t]{4}{*}{ Age $(y r)$} & \multirow[t]{4}{*}{$s-\operatorname{Ig} G(g / l)$} & \multicolumn{5}{|c|}{ Autoantibodies } \\
\hline & & & \multicolumn{3}{|l|}{$L M A^{*}$} & \multirow{3}{*}{$\begin{array}{c}A N A \\
I g G\end{array}$} & \multirow{3}{*}{$\begin{array}{l}S M A \\
\operatorname{Ig} G\end{array}$} \\
\hline & & & \multirow{2}{*}{$\begin{array}{l}\text { Human } \\
\operatorname{Ig} G\end{array}$} & \multicolumn{2}{|c|}{ Rabbit $\uparrow$} & & \\
\hline & & & & $\operatorname{Ig} G$ & $I g G \cdot F a b_{2}$ & & \\
\hline 1 & 37 & $21 \cdot 6$ & + & - & - & + & - \\
\hline 2 & 16 & $73 \cdot 2$ & + & + & $\therefore$ & + & + \\
\hline 3 & 57 & $34 \cdot 1$ & $t$ & + & + & $t$ & + \\
\hline 4 & 52 & $53 \cdot 2$ & + & + & + & + & + \\
\hline 5 & 34 & $24 \cdot 5$ & $\div$ & + & + & - & - \\
\hline 6 & 68 & $38 \cdot 3$ & 4 & + & -+ & + & - \\
\hline 7 & 52 & $19 \cdot 7$ & + & $\div$ & + & + & - \\
\hline 8 & 64 & $36 \cdot 3$ & + & + & + & + & + \\
\hline \multicolumn{8}{|l|}{ Controls } \\
\hline $9-16$ & $16-68$ & $7 \cdot 2-15 \cdot 1$ & - & - & - & - & - \\
\hline
\end{tabular}

* Liver membrane antibodies against hepatocytes.

†Sera No 2-8 also gave positive membrane reaction with hepatocytes from rat, guinea pig, and monkey.

Indirect IF technique was also employed using normal peripheral blood leucocytes and Raji cells. Leucocytes were isolated from defibrinated blood by the use of dextran-isopaque gradient according to the method described by Bøyum. ${ }^{10}$ These cells were used either smeared and fixed on glass slides or live, suspended in Eagle's minimal essential medium (Flow Laboratories) both with and without 0.034 M sodium citrate.

\section{ABSORPTION STUDIES}

Patients sera were diluted $1 / 4$ in PBS with $0 \cdot 2 \%$ human albumin and $0.1 \mathrm{ml}$ was incubated with $2.5 \mathrm{mg}$ of $\mathrm{F}$-actin from rabbit muscle (Sigma). The mixture was kept at $37^{\circ} \mathrm{C}$ for $30 \mathrm{~min}$ and at $4^{\circ} \mathrm{C}$ overnight. After centrifugation at $25000 \mathrm{~g}$ for 30 min, the supernatant was tested for LMA, ANA and SMA by indirect IF.

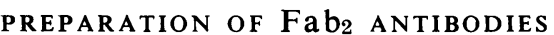

The immunoglobulin-fraction of patients sera was separated on a protein A sepharose CL column (Pharmacia, Sweden). A citrate buffer $\mathrm{pH} 2 \cdot 5$, was used for elution and the eluate was checked by spectrophotometry and the recovery of IgG by crossed and rocket immunoelectrophoresis. Pepsindigestion of this fraction was done using $2 \mathrm{mg}$ pepsin/100 $\mathrm{mg}$ of protein and incubation lasted $40 \mathrm{~h}$ at $\mathrm{pH} 4 \cdot 1$. The digestion was checked by polyacrylamide gel electrophoresis (PAG-kit, Pharmacia, Sweden) which included native human IgG as a reference standard ${ }^{11}$ and the Fab $_{2}$ fragments were then used to investigate binding to rabbit hepatocytes. and for IgG-Fc were from DAKO, Denmark. Slides were read in a Leitz Orthoplan microscope equipped for incident light illumination. ${ }^{4}$

\section{Results}

Eight sera were selected from female patients with biopsy-verified HBsAg-negative CAH (Table). All except one had the capacity to stain the membrane of rabbit, rat, guinea pig, and monkey hepatocytes giving a linear fluorescence pattern. There were no definite differences between the reactions against cells from the various species. Additionally, all eight sera reacted with isolated human hepatocytes giving a much stronger linear fluorescence than that obtained with non-human cells.

No linear staining of the plasma membrane was demonstrated by the eight patients' sera using fixed and smeared preparations of peripheral blood leucocytes or Raji cells. The four SMA-positive sera all gave a weak and diffuse cytoplasmic fluorescence on smeared preparations of these cells but only when the medium contained sodium citrate. Suspensions of Raji cells and of lymphocytes were completely negative by indirect IF with patients sera independent of chelating agent in the suspending medium. Contrary to that, the addition of sodium citrate to the washing medium, weakened or completely abolished the membrane staining of rabbit hepatocytes by LMA-positive sera. On the other hand, heat inactivation at $56^{\circ} \mathrm{C}$ for $30 \mathrm{~min}$ had no effect on the LMA reaction.

Sera from the eight patients were absorbed with F-actin, whereby all smooth-muscle staining disappeared, but antibodies against hepatocyte membrane and nuclear components were unaffected.

The eight control sera gave negative results by 
IF testing on the various cell preparations mentioned above, including human hepatocytes. This was independent of heat-inactivation prior to testing and whether cells were smeared or in suspension.

When serum was separated by protein Asepharose affinity chromatography, the IgG-recovery was $80-90 \%$ in all experiments. The LMA reactions of the IgG fractions were noticeably stronger as compared to serum. Pepsin-digestion was investigated with polyacrylamide gel electrophoresis. This showed heavy banding corresponding to IgG-Fab 2 and no intact IgG molecules. Seven sera were positive for LMA when using rabbit hepatocytes, and in all of these, $\mathrm{Fab}_{2}$ fragments gave linear membrane staining using conjugates specific for gamma chains, but never with conjugates specific for IgG-Fc. Reactions against other tissue components were likewise preserved after isolating $\mathrm{Fab}_{2}$ antibodies. The control sera were still negative for autoantibodies when they had been subjected to the same procedure of fractionation.

\section{Discussion}

When LMA was first demonstrated in patients with $\mathrm{CAH}$, rabbit hepatocytes were used as substrate. ${ }^{1}$ Later studies have confirmed that the membrane antigen involved is also present in normal human hepatocytes, ${ }^{9}$ but the exact nature of the antigen is not yet known. The present study underlines the ubiquitous existence of this LMAg which is also found in rodents and in monkey. The study further confirms that we are dealing with a true autoantibody that reacts with human hepatocytes.

Patients with HBsAg-negative CAH very often demonstrate SMA which were shown to be actinspecific. ${ }^{12}$ After absorption with F-actin from rabbit muscle in the present study and after the disappearance of high titre SMA in four patients, the LMA reaction was unaffected. Neither could we demonstrate any staining of actin in smeared Raji cells by LMA-positive sera, while there was a moderate cytoplasmic staining of these cells by SMA-positive sera. This is in accordance with Fagraeus et al, who also demonstrated that the reaction of SMA with lymphoblastoid cells was dependent on sodium citrate being present in the suspending medium. ${ }^{13}$ Chelating agent did not reverse the failure of LMA to stain Raji cells in our study. On the contrary the presence of sodium citrate negatively influenced the LMA reactivity with rabbit hepatocytes. This indicates that no crossreactivity exists between actin and the target antigen of LMA,14 and the LMA reaction might depend on divalent cations being present.

The study has further established that $\mathrm{Fab}_{2}$ fragments of LMA-positive sera retain the capacity to stain the membranes of isolated hepatocytes which excludes that this binding is normally due to receptors for IgG-Fc, that were shown to be present on these cells by Hopf et al. ${ }^{15}$ Interestingly, the separated IgG as well as the Fab2 fragments gave stronger LMA reactions than the corresponding serum in the same dilutions. It is possible that some sort of inhibitor is present in the serum, or liver membrane antigen-antibody complexes are dissociated resulting in a release of free antibodies.

It is concluded that LMA detected by immunofluorescence represents specific binding of antibodies against non-species-specific membrane antigens that are normal constituents of hepatocytes. The LMAg is located apart from and is definitely not crossreacting with F-actin. In contrast to SMA the IF demonstration of LMA seems to require calcium.

This study was supported by the Danish Medical Research Council (Grant No 512-15478).

\section{References}

${ }^{1}$ Hopf U, Meyer zum Büschenfelde K-H, Arnold W. Detection of a liver-membrane autoantibody in $\mathrm{HBsAg}$ negative chronic active hepatitis. $N$ Engl J Med 1976; 294:578-82.

2 Tage-Jensen U, Arnold W, Dietrichson O et al. Liver-cellmembrane autoantibody specific for inflammatory liver diseases. $\mathrm{Br}$ Med J 1977; ; :206-8.

${ }^{3}$ Manthorpe R, Permin H, Tage-Jensen U. Autoantibodies in Sjögren's syndrome, with special reference to liver cell-membrane antibody (LMA). Scand $J$ Rheumatol $1979 ; 8: 168-72$.

${ }^{4}$ Tage-Jensen U, Permin H, Hardt F et al. Circulating autoantibodies in patients with acute viral hepatitis. Relation to etiology and clinical course. Scand $J$ Gastroenterol 1980;15:229-35.

${ }^{5}$ Gluud C, Tage-Jensen U, Bahnsen M, Dietrichson $O$, Svejgaard A. Autoantibodies, histocompatibility antigens and testosterone in males with alcoholic liver cirrhosis. Clin Exp Immunol 1981;44:31-7.

- Meyer zum Büschenfelde K-H, Miescher PA. Liverspecific antigens: purification and characterisation. Clin Exp Immunol 1972;10:89-102.

${ }^{7}$ Meyer zum Büschenfelde K-H, Manns M, Hütteroth TH, Hopf U, Arnold W. LMAg and LSP-two different target antigens involved in the immunopathogenesis of chronic active hepatitis? Clin Exp Immunol 1979;37: 205-12.

${ }^{8}$ Trenchev $P$, Sneyd P, Holborow EJ. Immunofluorescent tracing of smooth muscle contractile protein antigens in tissues other than smooth muscle. Clin Exp Immunol 1974;16:125-36.

${ }^{9}$ Krogsgaard K, Tage-Jensen U, Wantzin P, Aldershvile J, Hardt F. Localisation of immunoglobulin on the liver cell surface in primary biliary cirrhosis. J Clin Pathol $1981 ; 34: 1076-9$.

${ }^{10}$ Bøyum A. Separation of white blood cells. Nature 1964; 204:793-5.

${ }_{11}$ O'Farrell PH. High resolution two-dimensional electrophoresis of proteins. $J$ Biol Chem 1975;250:4007-21.

${ }^{12}$ Lidman K, Biberfeld G, Fagraeus A et al. Anti-actin 
specificity of human smooth muscle antibodies in chronic active hepatitis. Clin Exp Immunol 1976;24:266-72.

${ }^{13}$ Fagraeus A, Lidman K, Norberg R. Indirect immunofluorescence staining of contractile proteins in smeared cells by smooth muscle antibodies. The influence of chelating agents. Clin Exp Immunol 1975;20:469-77.

14 Miettinen A. Liver-membrane autoantibody in HBsAgnegative chronic active hepatitis. $N$ Engl J Med 1976;295: $105-6$.
${ }^{15}$ Hopf U, Meyer zum Büschenfelde K-H, Dierich MP. Demonstration of binding sites for IgGFc and the third complement component (C3) on isolated hepatocytes. $J$ Immunol 1976;117:639-45.

Requests for reprints to: Dr $U$ Tage-Jensen, MD, Department M, Rigshospitalet, Tagensvej 18, DK-2200 Copenhagen N, Denmark. 